\title{
Epicardial Adipose Tissue Thickness, A Direct Correlation With Age And Gender In Healthy Adults And Coronary Artery Disease Patients
}

\author{
Sadaf Shaheen, Sahrish Mukhtar, Iffat Raza, Bashir Sheikh
}

ABSTRACT

Objectives: The aim of this study was to measure the Epicardial Adipose Tissue thickness through echocardiography in healthy adults and coronary artery disease patients and to make its association with age and gender.

Methods: It was a case control study. A total of 315 samples including 159 cases of coronary artery disease and 156 asymptomatic individuals for coronary artery disease underwent echocardiography for Epicardial Adipose Tissue thickness measurement.

Results: Mean Epicardial Adipose Tissue (EAT) in the study was found to be $15.45 \pm 7.16 \mathrm{~mm}$. Cases had significantly higher EAT $16.77 \pm 9.80 \mathrm{~mm}$ as compared to controls $14.13 \pm 4.52 \mathrm{~mm}(\mathrm{P}=0.02)$. EAT thickness increased significantly with age $(\mathrm{P}=0.004)$. There was no significant difference of EAT $(\mathrm{P}=0.999)$ in both the genders.

Conclusion: The mean EAT thickness is significantly higher in our study population as compared to previous studies. The mean EAT thickness was same in both males and females of our study. There was no significant difference in EAT of both genders.

Key Words: Epicardium, Epicardial adipose tissue, Epicardial adiposetissue thickness, Coronary artery disease, Echocardiography, Cardiovascular risk, Myocardial fat, Visceral fat depot, Lean body mass, Myocardial infarction.

\section{INTRODUCTION:}

Epicardial adipose tissue (EAT) is an independent factor in the development of coronary artery disease ${ }^{1}$. It is responsible for fatal and nonfatal coronary artery events in general population irrespective of cardiovascular risk factors ${ }^{2}$. EAT is the visceral fat depot of the heart ${ }^{3}$. EAT is a metabolically active organ with anatomical and functional contiguity to the myocardium ${ }^{4}$. It is the most significant independent correlation of myocardial fat ${ }^{5}$. EAT has anatomic and functional proximity to the myocardium and it has intense metabolic activity, therefore some interactions between heart and its visceral fat depot has been suggested ${ }^{6}$.

EAT has endocrine and paracrine activity ${ }^{7,8}$. It secretes proinflammatory and anti- inflammatory cytokines and chemokines $\mathrm{s}^{9,10}$. It is suggested that these chemicals promote the development of coronary artery atherosclerosis ${ }^{11,12,13}$. Various researchers from different parts of the world have

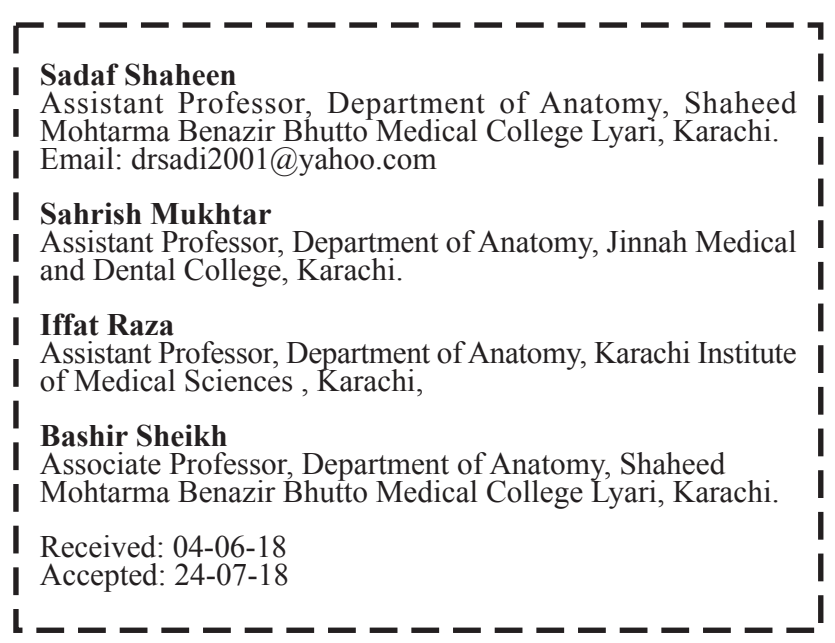

reported that EAT thickness varies with age and gender ${ }^{14}$. EAT increases with increase in age ${ }^{15,13,16}$. EAT mass increases with age, until the age of 20-40 years, but is not dependent on age in later life ${ }^{17}$. EAT is $22 \%$ thicker in individuals older than 65 years $^{18}$. Lean body mass decreases with aging whereas visceral fat mass increases because of redistribution of fat in trunk and viscera ${ }^{19}$. These changes seem to occur at a different rate and intensity between men and women, with a greater redistribution seen in older women ${ }^{20}$.

There is no literature available on the association of gender with EAT thickness. From the Framingham cohort study data, Rosito et. $\mathrm{al}^{21}$ suggested that there is more association between EAT thickness and risk factors for coronary artery disease (CAD) in women than in men. However, two other studies of the same cohort did not find this association ${ }^{11,15}$. Taking this into consideration, it is not possible to attribute these differences to the gender or to other concomitant characteristics ${ }^{22}$. Gender, race and genes are also responsible for the occurrence of CAD ${ }^{23}$.

Determinations of normal EAT according to the population's own age and gender has now become essential for future prediction of having chances of coronary artery disease. Epicardial adipose tissue has been identified to play a crucial role in the pathogenesis of coronary artery disease $\mathrm{e}^{24}$. Its thickness may serve as a new index of cardiac and visceral adiposity with potential as a diagnostic tool and therapeutic target in myocardial infarction. Increase EAT thickness may be associated with poor prognosis in patients with acute coronary syndrome ${ }^{25}$. The objectives of this study were to determine EAT thickness in a subset of Karachi population and also to determine the effects of age and gender on EAT thickness. 


\section{MATERIAL AND METHODS:}

This was a case-control study carried out from September 2014 to February 2015. Three Hundred and Fifteen volunteers participated in the study and went through echocardiographic examination at Echo cardiology Department of Ziauddin Hospital Clifton, Karachi. The study was conducted after taking approval from Ethical Review Committee, Ziauddin University, Karachi. Samples were collected after taking a written informed consent. Proforma regarding subject's history and demographic profile was filled. All those healthy individuals with incidental findings of coronary artery disease or any other cardiac pathology on echocardiography, history of cardiac disease and cardiomyopathy, pregnancy, hypertension, diabetes, any major cardiac surgical history, history of usage of alcohol, history of anti hypertensive and anti arrhythmic drugs, left chest irradiation, current use of oral corticosteroid and chest deformity were excluded from the study.

Echo machine Toshiba model NemioXG with cardiac probe frequency of 3.5 MHz was used to determine EAT thickness of our sample population. Participant was examined in supine position, with pillow under their shoulders to make comfortable position. EAT thickness was measured by sub costal view, parasternal long axis view and parasternal short axis views. The mean EAT was then calculated. Data was entered on Microsoft Excel and SPSS version 20 was used

\begin{tabular}{|c|c|c|}
\hline & Frequency & Percent \\
\hline $35-44$ & 76 & 24.1 \\
\hline $45-54$ & 91 & 28.9 \\
\hline $55-64$ & 60 & 19.0 \\
\hline $65-74$ & 56 & 17.8 \\
\hline $75-85$ & 32 & 10.2 \\
\hline Total & 315 & 100 \\
\hline
\end{tabular}

Table 1: Age Distribution of Study Participants

\begin{tabular}{|l|l|l|l|l|l|}
\hline & $\begin{array}{c}\text { Disease } \\
\text { status }\end{array}$ & N & Mean & $\begin{array}{c}\text { Std. } \\
\text { Deviation }\end{array}$ & P-value \\
\hline \multirow{2}{*}{ EAT $(\mathrm{mm})$} & control & 157 & 14.1325 & 4.52136 & \multirow{2}{*}{0.002} \\
\cline { 2 - 6 } & case & 156 & 16.7718 & 9.80318 & \\
\hline
\end{tabular}

Table3: Mean EAT in Cases and Controls for statistical analysis. Means and standard deviations were derived for numerical variables and ANOVA was applied to determine the significance among age groups. Paired ttest was used to compare the difference of EAT with age and gender. Independent T-test was applied to calculate significance between genders and for age. P- Value of $<$ 0.05 was considered to be significant.

\section{RESULTS:}

The mean age of the study participants was $55.16 \pm 13.79$ years. The minimum and maximum age of the volunteers ranged from 35 to 80 years. $50.2 \%$ (158 out of 315 ) were males and $49.8 \%$ ( 157 out of 315 ) were females with their mean age $54.36 \pm 14.54$ and $55.96 \pm 12.98$ years respectively. EAT thickness increased significantly with age $(\mathrm{P}$ value $=$ $0.004)$. Weak positive $(\mathrm{r}=0.162)$ association was found between EAT and age of cases and controls. Mean Epicardial Adipose Tissue thickness of 157 controls was found to be $14.13 \pm 4.5 \mathrm{~mm}$, while mean Epicardial Adipose Tissue thickness of 156 cases was found to be $16.77 \pm 9.80 \mathrm{~mm}$. Significant difference of mean EAT (P-value $=0.002)$ was found between cases and controls. Mean EAT in males was $15.44 \pm 9.8$ and in females it was $15.44 \pm 4.8$. No significant difference of mean EAT between males and females was found. $(\mathrm{P}$-value $=0.999)$.

\section{DISCUSSION:}

The mean age of the study participants was $55.16 \pm 13.79$

\begin{tabular}{|c|c|c|}
\hline Gender & Frequency & Percent \\
\hline Male & 158 & 50.2 \\
\hline Female & 157 & 49.8 \\
\hline Total & 315 & 100.0 \\
\hline
\end{tabular}

Table 2: Gender Distribution of Study Participants

\begin{tabular}{|l|l|c|c|c|c|}
\hline & Gender & $\mathrm{N}$ & Mean & $\begin{array}{c}\text { Std. } \\
\text { Deviation }\end{array}$ & P-value \\
\hline \multirow{2}{*}{ EAT $(\mathrm{mm})$} & Male & 156 & 15.4487 & 9.82080 & \multirow{2}{*}{0.999} \\
\cline { 2 - 5 } & Female & 157 & 15.4471 & 4.85730 & \\
\hline
\end{tabular}

Table4: Mean EAT in Males and Females

\begin{tabular}{|c|c|c|c|c|}
\hline \multirow{2}{*}{$\mathrm{R}$} & \multirow{2}{*}{ R Square } & \multirow{2}{*}{ P-value } & \multicolumn{2}{|c|}{$95.0 \%$ Confidence Interval for B } \\
\cline { 4 - 5 } & & & Lower Bound & Upper Bound \\
\hline \multirow{2}{*}{0.162} & \multirow{2}{*}{0.026} & \multirow{2}{*}{.004} & 6.901 & 13.949 \\
\cline { 4 - 5 } & & & .029 & 0.153 \\
\hline
\end{tabular}

Table5: Correlation of EAT with Age 
Epicardial Adipose Tissue Thickness, A Direct Correlation With Age And Gender In Healthy Adults And Coronary Artery Disease Patients

\begin{tabular}{|c|c|c|c|c|}
\hline Age groups & Mean & $\mathbf{N}$ & Std. Deviation & P-value \\
\hline $35-44$ & 12.4013 & 76 & 4.09873 & \\
\cline { 1 - 4 } $45-54$ & 15.8923 & 91 & 4.62736 & \\
\cline { 1 - 4 } $55-64$ & 15.5500 & 60 & 5.10123 & \multirow{2}{*}{0.999} \\
\cline { 1 - 4 } $65-74$ & 16.8500 & 56 & 5.56283 & \\
\cline { 1 - 4 } $75-84$ & 15.2688 & 32 & 5.95003 & \\
\cline { 1 - 4 } Total & $\mathbf{1 5 . 0 9 1 7}$ & $\mathbf{3 1 5}$ & $\mathbf{5 . 1 4 6 6 0}$ & \\
\hline
\end{tabular}

Table 6: EAT in Age Groups

years. We found a significant difference in EAT with increasing age. A weak positive $(r=0.162)$ (table 5) association was found between EAT and age of cases and controls. Our results were in accordance with the results of previous studies done $26,27,28,29$. The reason for this gradual increase in EAT thickness with age is that there is a decrease in lean body mass and increase in fat mass, with fat tissue redistribution to the trunk and viscera suggested by Dey DK, 1999. Epicardial adipose tissue is more abundant in the elderly and is correlated to visceral adipose tissue depots, indicating a higher cardio metabolic risk ${ }^{26}$.

The mean EAT thickness was same in both males and females of our study (table 4). We found no significant difference in EAT of both genders. A study done by Dagvasumbere $\mathrm{M}^{30}$ concluded that mean EAT was higher in men in CAD group than in non-CAD group. There was no consensus in the previous literature on the association of gender on the amount of EAT. The Framingham ${ }^{31}$ cohort data suggested that EAT is more associated with risk factors in women than in men. Two other studies from the same cohort suggested this association of gender with EAT $^{32,33}$. Our study result was also in accordance with the results of previous studies $^{30,32,33}$.

Mean EAT thickness in our study controls groups were found to be $14.13 \pm 4.5 \mathrm{~mm}$, while in case of CAD group it was found to be $16.77 \pm 9.80 \mathrm{~mm}$ (table 3). Significant difference of mean EAT (P-value 0.002) was found between cases and controls (table 3 ). EAT thickness in healthy adults noted by different researchers in different regions of the world was as follows: in Asian-Indians $2.6 \pm 1.3 \mathrm{~mm}^{34}$, $3.43 \pm 0.88 \mathrm{~mm}^{35}$ and $9.97 \pm 2.88 \mathrm{~mm}$ in Italy $^{36}$. Mean EAT thickness in our studied population was highest than the other studied populations.

The mean EAT in CAD patients in our studied group was found to be $16.77+9.80 \mathrm{~mm}$ (table 3 ) while it was found different by other researchers like $<5 \mathrm{~mm}, 2.34 \pm 0.89 \mathrm{~mm}^{35}$ and $3.4 \pm 2.2 \mathrm{~mm}^{37}$. The reason for this increase in difference of EAT perhaps due to a higher number of overweight and obese subjects in our studied group.

\section{CONCLUSION:}

The mean EAT thickness is significantly higher in our study population as compared to previous studies. We found

gradual increase in EAT with age until the age of sixty four year, after that it became static. The mean EAT thickness was same in both males and females in our study. We found no significant difference in EAT of both genders. Echocardiographic Epicardial Adipose tissue is an inexpensive, reproducible, and direct measure of visceral fat. It may have an important role in predicting and stratifying cardiovascular risk in clinical care.

\section{REFERENCES:}

1. Ahn SG, Lim HS, Joe DY, Kang SJ, Choi BJ, Choi SY, Yoon MSH, Hwang GS, Tahk SJ, Shin JH et al. Relationship of epicardial adipose tissue by echocardiography to coronary artery disease. British J Cardiology. 2008; 94(3).

2. Amir A.Mahabad, Marie H.Berg, Lils Lehmann, Hagen Kalsch, Marcus Bauer, Kaffer Kara et all.Association of Epicardial Adipose tissue with cardiovascular risk factors and incident myocardial infarction in the general population. J Am Coll Cardiol, 2013;61(13):1388-95.

3. Lacobellis G. Relation of Epicardial Adipose tissue thickness to right ventricular cavity size in obese subjects. Am J Cardiol. 2009;104(11):1601-2.

4. Lacobellis G, Malavazos AE, Corsi MM. Epicardial Adipose tissue: from the biomolecular aspects to the clinical practice. Int J Biochem Cell Biol. 2011;43(12):1651-4.

5. Malavazos AE, Di Leo G, Iacobellis G. Relation of echocardiographic Epicardial Adipose tissue thickness and myocardial fat. Am J Cardiology. 2010;105(12):1831-5.

6. Willens HJ, Gómez-Marín O, Iacobellis G. Comparison of epicardial and pericardial fat thickness assessed by echocardiography in African American and non-Hispanic White men. J Ethn Dis. 2008;18(3):311-6.

7. Arita T, Kihara S,Ouchi N, Adipocyte- derived plasma protein adiponectin acts as a platet-derived growth factor-BB-binding protein and regulates growth factor-induced common postreceptor signal in vascular smooth muscle cell. Circulation. 2002;105:2893-98.

8. Mazurek. T, Zhang L, Zalewski A, Human epicardial adipose tissue is a source of inflammatory mediators. Circulation 2003:108:2460-66

9. Hirata Y, Tabata M, Kurobe H. Coronary atherosclerosis is associated with macrophage polarization in epicardial adipose tissue.A Am Coll Cardiol. 2001;58:248-255.

10. Laine P, Kaartinen M, Penttila A,Panula P, Paavonen T, Kovanen P.T. Association between myocardial infarction and the mast cells in the adventitia of the infarct-related coronary artery.Circulation 1999;99:361-369.

11. Mahabadi A.A, Reinsch N, Lehmann N, Association of pericoronary fat volume with atherosclerotic plaque burden in the underlying coronary artery: a segment analysis. Atherosclerosis. 2010;2011:195-199

12. Bettencourt N, Toschke A.M, Leite D, Epicardial adipose tissue is an independent predictor of coronary atherosclerotic burden. Int J Cardiol. 2012;158:26-32.

13. Alexopoulos N, Mclean D.S, Janik M, Arepalli C.D, Stillman A.E, Raqqi P. Epicardial adipose tissue and coronary artery plaque characterirtics. Atherosclerosis. 2010;2010:150-154

14. Shetty R, Correlation of Epicardial Adipose tissue and anthropometric measurements in Asian-Indians. Avicenna 
Journal of Medicine. 2012; 2(4):89-93.

15. Fox CS, Gona P, Hoffmann U, Porter SA, Salton CJ, Massaro $\mathrm{JM}$, et al. Pericardial fat, intrathoracic fat, and measures of left ventricular structure and function: the Framingham Heart Study. Circulation.2009;119(12):1586-91.

16. Silaghi A, Piercecchi-Marti M-D, Grino M, Leonetti G, Alessi MC, Clement K, et al. Epicardial adipose tissue extent: relationship with age, body fat distribution, and coronaropathy. Obesity. 2008;16(11):2424-30.

17. Rabkin SW. Epicardial fat: properties, function and relationship to obesity. J Obesity. 2007;8(3):253-261.

18. Abbara S, Desai JC, Cury RC, Butler J, Nieman K, Reddy V. Mapping Epicardial Adipose tissue with multi-detector computed tomography to facilitate percutaneous transepicardial arrhythmia ablation. Eur J Radiol.2006;57(3):417-422.

19. Dey DK, Rothenberg E, Sundh V, Bosaeus I, Steen B. Height and body weight in the elderly. I. A 25 -year longitudinal study of a population aged 70 to 95 years. Eur J Clin Nutr. 1999;53(12):905-914.

20. Perissinotto E, Pisent C, Sergi G, Grigoletto F. Anthropometric measurements in the elderly: age and gender differences. $\mathrm{Br}$ J Nutr. 2002;87(2):177-186.

21. Rosito GA, Massaro JM, Hoffmann U, Ruberg FL, Mahabadi AA, Vasan RS, et al. Pericardial fat, visceral abdominal fat, cardiovascular disease risk factors, and vascular calcification in a community-based sample: the Framingham Heart Study. Circulation. 2008;117 (5):605-13.

22. Bertaso AG, Bertol D, Duncan BB, Foppa M et al. Epicardial Adipose tissue: Definition, Measurements and Systematic Review of Main Outcomes. Arq Bras Cardiol. 2013;101(1): e18-e28.

23. Kenchaiah S, Evans JC, Levy D, Wilson PW, Benjamin EJ, Larson $\mathrm{G}$, et al. Obesity and the risk of heart failure. N Engl J Med 2002; 347(5): 305-13.

24. Willens HJ, Go'mez-Marý'n O, et all. Comparison of epicardial and pericardial fat thickness assessed by echocardiography in african american and non-hispanic white men. 2008; 18: 311-6.

25. Park EM, Choi JH. Echocardiographic Epicardial Adipose tissue thickness on short term prognosis in patients with acute coronary syndrome. J Cardiovascular Ultrasound 2008; $16(2): 42-47$.

26. Mazzoccoli G, Dagostino MP, Greco A, Age-related changes of Epicardial Adipose tissue thickness. Biomedicine \& Preventive Nutrition, 2012;(2)1:38-41.

27. Rabkin SW, The relationship between Epicardial Adipose tissue and indices of obesity and the metabolic syndrome: a systematic review and meta-analysis. Metab Syndr Relat Disord. 2014;12(1):31-42.
28. Silaghi A, Piercecchi-Marti MD, Grino M, Leonetti G, Alessi MC, Clement K, Dadoun F, Dutour A et all, Epicardial Adipose Tissue Extent: Relationship With Age, Body Fat Distribution, and Coronaropathy. 2008, 16(11), 2424-30.

29. Crendal E, Dutheil F, Naughton G, McDonald T, Obert P. Increased myocardial dysfunction, dyssynchrony, and Epicardial Adipose tissue across the lifespan in healthy males.BMC Cardiovascular Disorders 2014;14:95

30. Dagvasumberel M, Shimabukuro M, Nishiuchi T, Ueno J, Takao S, Fukuda D et all. Gender disparities in the association between epicardial adipose tissue volume and coronary atherosclerosis: A 3-dimensional cardiac computed tomography imaging study in Japanese subjects.Cardiovascular Diabetology 2012, 11:106.

31. Rosito GA, Massaro JM, Hoffmann U, Ruberg FL, Mahabadi AA, Vasan RS, et al. Pericardial fat, visceral abdominal fat, cardiovascular disease risk factors, and vascular calcification in a community-based sample: the Framingham Heart Study. Circulation. 2008;117(5):605-613.

32. Mahabadi AA, Massaro JM, Rosito GA, Levy D, Murabito JM, Wolf PA, et al. Association of pericardial fat, intrathoracic fat, and visceral abdominal fat with cardiovascular disease burden: the Framingham Heart Study. Eur Heart J. 2009;30 (7):850-6.

33. Shmilovich H, Dey D, Cheng VY, Rajani R, Nakazato R, Otaki Y, et al. Threshold for the upper normal limit of indexed Epicardial Adipose tissue volume: derivation in a healthy population and validation in an outcome-based study. Am J Cardiol. 2011;108(11):1680-85.

34. Shetty R, Vivek G, Naha K, Nayak K, Goyal A, Dias LS et all, Correlation of Epicardial Adipose tissue and anthropometric measurements in Asian-Indians. Avicenna J Med. 2012; 2(4): 89-93.

35. Gedikli O, Ozturk M, Turan OE, Ilter A, Hosoglu Y, Kiris G, Epicardial adipose tissue thickness is increased in patients with cardiac syndrome X. International Journal of Clinical \& Experimental Medicine;2014; 7(1): 194

36. Iacobellis G, Assael F, Ribaudo MC, Zappaterreno A, Alessi G, Di Mario U, Leonetti F. Epicardial Adipose tissue from echocardiography: a new method for visceral adipose tissue prediction. Obes Res. 2003;11(2):304-10.

37. Park JS, Choi SY, Zheng M, Yang HM, Lim HS, Choi BJ, Yoon MH, Hwang GS, Tahk SJ, Shin JH. Epicardial adipose tissue thickness is a predictor for plaque vulnerability in patients with significant coronary artery disease. Atherosclerosis. 2013an; 226(1):134-9. 